\title{
Daria KOWALCZYK-CANTORO
}

Uniwersytet Wrocławski

(iD) https://orcid.org/0000-0001-6768-8063

\section{RENESANSOWY POEMAT SARCA JAKO AEMULATIO Z AUTORAMI ANTYCZNYMI}

\author{
RENAISSANCE POEM SARCA AS AEMULATIO WITH ANCIENT AUTHORS
}

The aim of this article is to analyse the Renaissance poem Sarca, whose authorship is attributed to the Italian humanist Pietro Bembo, and to indicate the ancient inspirations of the work. The main model for the work is Carmen 64 by Catullus, although the author also refers to other Roman poets. The intertextual relations between Sarca and the hypotexts are presented on various levels. The analysis focuses on showing parallel elements of the setting and takes in consideration the few similarities at the linguistic and stylistic level. Genre-wise Sarca is classified as an epithalamium of an aythiological character. Its characteristics typical of the Renaissance era are also highlighted. The article also brings up the history of the poem and the topic of its attribution, presenting an extensive state of research.

Keywords: Pietro Bembo, Catullus, Renaissance, aemulatio, epithalamium, Neo-Latin Literature Słowa kluczowe: Pietro Bembo, Katullus, renesans, aemulatio, epithalamium, neolatynistyka

Poemat Sarca, którego autorstwo przypisuje się weneckiemu humaniście Pietrowi Bembowi, datuje się na lata trzydzieste XVI wieku. Ten łaciński tekst, liczący 619 heksametrów, nazwany przez Jacoba Burckhardta „renesansowym arcydziełem, które poszerza i uzupełnia grecko-rzymską mitologię" (Chatfield 2005: XII; tłum. własne), został wydany w 1842 roku w Rzymie przez Angela Maia na podstawie rękopisu znalezionego w Wiedniu. W pierwszej części utworu poeta opowiada historię miłości bóstwa rzeki Sarki, mającej swoje źródła w Alpach wschodnich, do nimfy Gardy, córki Benakusa, który w poemacie jest rzeką, i nimfy masywu Monte Baldo. W kolejnych wersach zawarty jest obszerny opis ceremonii zaślubin bohaterów. Punkt kulminacyjny poematu stanowi przepowiednia tebańskiej wieszczki Manto, według której ze zjednoczenia wód Sarki 
i Benakusa, będącego przypieczętowaniem małżeństwa, powstanie jezioro Garda, a z niego wypłynie rzeka Mincio przepływająca przez Mantuę, miasto narodzin Wergiliusza. Dalsza część poematu stanowi opis i pochwałę twórczości Wergilego, którego Bembo nazywa rodzicem wszystkich wieszczy i pełnym czci kapłanem Muz. Bembo wychwala również poetów, którzy inspirowali się twórczością Wergiliusza. Wspomina tu między innymi współczesnych sobie Pontana czy Sannazara, pochodzących z okolic Neapolu, gdzie spoczywa ciało Wergiliusza. Jak słusznie zauważa Mary P. Chatfield, „hołd złożony Wergiliuszowi zdaje się płynąc nieprzerwanie wraz z nurtem rzeki Mincio i scala się z pochwałą poetów współczesnych Bembowi” (Chatfield 2005: XVIII; thum. własne).

Na osobną uwagę zasługuje kwestia autorstwa poematu. W roku 1719 Apostolo Zeno napisał w liście do swojego brata Piera Caterina, że odnalazł w bibliotece wiedeńskiej pewien niepublikowany wcześniej poemat Bemba (Zeno 1782: 30). Nie podaje jednak ani jego tytułu, ani treści. Zważywszy na fakt, iż w wydanym przez siebie dziesięć lat później zbiorze całości dorobku artystycznego humanisty ${ }^{1}$ Zeno nie umieszcza Sarki, stwierdzić można, że wspominając o znalezionym rękopisie miał na myśli inne dzieło. Bez odpowiedzi jednak pozostaje pytanie - jakie. Ponad sto lat po wydaniu Zena ukazuje się ósmy tom Spicilegium Romanum Angela Maia (Mai 1942), w którym autor umieszcza streszczenie Sarki oraz sam poemat liczący 498 wersów. Badacz, wspominając, że zna rękopis Sarki z listu Zena (Pighi 1974: 51), za oczywiste uznał, iż ten, pisząc o znalezionym w Wiedniu manuskrypcie, miał na myśli właśnie ów utwór. Zastanawiający jednak wydaje się fakt, że Mai nie opisał włoskiego egzemplarza, z którego korzystał, zamieszczając poemat w Spicilegium Romanum. Niezgodność Sarki wydanej przez Maia z rękopisem wiedeńskim jako pierwszy zauważa Bernardo Morsolin (1886-1887: 235). Badacz twierdzi, że poemat opublikowany w Spicilegium Romanum znacznie różni się od wiedeńskiego rękopisu, który znał Zeno i którego kopii sam jest posiadaczem. Ponadto Morsolin uzupełnia edycję Sarki Maia o dodatkowe 121 wersów.

W drugiej połowie ubiegłego stulecia rozpoczyna się polemika podważająca teorię, wcześniej uznawaną za pewną, że autorem Sarki miał być Pietro Bembo. Głos w tej sprawie jako pierwszy zajmuje Marco Pecoraro, zauważając, że po 1511 roku w listach pisanych przez Bemba nie ma żadnych wzmianek o jego łacińskich dziełach (Pecoraro 1959: 223). W świetle tej informacji wydawałoby się, że po

${ }^{1}$ Mowa o wydanym przez Apostola Zena i Antona Federiga Seghezziego czterotomowym zbiorze zawierającym całość zarówno włoskiej, jak i łacińskiej twórczości Bemba (Opere del cardinale Pietro Bembo ora per la prima volta tutte in un corpo unite, Venezia 1729). Jest to pierwsza i jedyna jak do tej pory próba zebrania ogółu lirycznej i prozatorskiej twórczości Bemba. Tom pierwszy zawiera Storia Veneta, zarówno po łacinie, jak i w języku volgare, w tomie drugim znajdziemy Rime, Gli Asolani oraz Prose della volgar lingua, a więc całość włoskiego pisarstwa Bemba, w trzecim tomie umieszczono listy pisane w volgare, Lettere volgari, natomiast na tom czwarty składają się korespondencja, dialogi i pieśni w języku łacińskim. 
1511 roku humanista nie pisał już utworów w języku łacińskim, a nie ma wątpliwości co do faktu, iż Sarka została napisana po roku $1526^{2}$. Dziesięć lat po opublikowaniu opracowania Pecorara W. Theodor Elwert zdecydowanie stwierdza, że autorem Sarki nie jest Bembo (Elwert 1969). Kwestię autorstwa poematu podjął również Emilio Piovesan (1974), twierdząc, że mógł on zostać napisany przez Pietra Bemba, Agostina Beazzana, Girolama Fracastora lub Andreę Navagera. W roku 1974 ukazało się wydanie Sarki wraz z przekładem na język włoski Giovanniego Battisty Pighiego. Tłumacz w przedmowie do wydania szczegółowo omówił dyskusję na temat autorstwa Sarki oraz przedstawił historię jej edycji. Sam twierdzi, że prawdopodobieństwo, iż Bembo napisał poemat, jest znikome. Trudno jednak z całą pewnością odpowiedzieć na pytanie, kto jest autorem tego renesansowego utworu. Innego zdania jest Otto Schönberger, który w 1994 roku przetłumaczył poemat na język niemiecki (Schönberger 1994). We wstępie do niemieckiego wydania podkreślił, że nie ma wątpliwości odnośnie atrybucji tekstu. $Z$ całą pewnością stwierdza, że autorem Sarki jest Pietro Bembo. Jego tezę popiera Mary P. Chatfield w przedmowie do wydanego i przetłumaczonego przez siebie w 2005 roku na język angielski zbioru łacińskiej twórczości Bemba (2005). Badaczka ponadto próbuje znaleźć odpowiedź na pytanie, dlaczego Bembo nie zdecydował się na wydanie poematu (Chantfield 2005: XVII-XIX). Ostatni jak na razie głos w sprawie autorstwa tekstu zabrał Martin Korenjak, który nazwał Sarkę anonimowym poematem błędnie przypisywanym Pietrowi Bembowi (Korenjak 2012: 531).

Sarca stanowi przykład renesansowego epitalamium. Głównym tematem utworu są wszak zaślubiny. Ponadto w tekście znajdujemy liczne motywy charakterystyczne dla tego gatunku, zwłaszcza dla jego narracyjno-mitologicznej odmiany. Autor Sarki wzorował swoje dzieło na jednym z najsłynniejszych utworów opisujących zaślubiny bogów. Mowa oczywiście o Katullusowej Pieśni 64. Obydwa teksty łączy wiele podobieństw, począwszy od samej tematyki, poprzez budowę utworu, kończąc na poszczególnych motywach. Na analogię między Sarka a Carmen 64 zwracali uwagę między innymi Mary P. Chatfield (2005: XVII) oraz Martin Korenjak (2012: 531). Żaden z badaczy nie wskazał jednak konkretnych przykładów ilustrujących owe podobieństwa. Nikt też nie zajął się analizą intertekstualną poematu ani nie zestawił go z innymi dziełami antycznymi.

Charakterystyczną cechą Carmen 64 i Sarki jest związanie ich ze „światem wodnym". Co prawda Katullus, w przeciwieństwie do renesansowego poety, nie umieszcza akcji utworu w tymże świecie, jednak już w pierwszych wersach, przywołując początek wyprawy po złote runo, wprowadza czytelnika w „morską atmosferę toni Neptuna”, „błękitnych przestworzy” i ,zabielających się pianą rozdzieranych wiosłem fali" (Katullus 2005: 79).

${ }^{2}$ Bembo miał napisać Sarkę, zajmując już stanowisko historiografa i bibliotekarza Republiki Weneckiej, ale nie będąc jeszcze kardynałem. Ponadto poeta wspomina o dziele Sannazara De partu Virginis, które wydane zostało w 1526 roku. Stąd też wnioskować można, że Sarca napisana została pomiędzy rokiem 1530 a 1539. 
Peliaco quondam prognatae vertice pinus dicuntur liquidas Neptuni nasse per undas Phasidos ad fluctus et fines Aeetaeos, cum lecti iuvenes, Argiuae robora pubis, auratam optantes Colchis avertere pellem ausi sunt vada salsa cita decurrere puppi, caerula verrentes abiegnis aequora palmis.

(...)

illa rudem cursu prima imbuit Amphitriten; quae simul ac rostro ventosum proscidit aequor tortaque remigio spumis incanuit unda, emersere freti candenti e gurgite vultus aequoreae monstrum Nereides admirantes.

1-7; 11-15 (Katullus 2013: 392).

Podobnie czyni autor Sarki, z tą jednak różnicą, że jego świat przedstawiony jest słodko-, a nie słonowodny. Renesansowy poeta po krótkiej inwokacji do Muz przedstawia Sarkę jako Alpinos inter clarissimus amnes. Opisując bóstwo, autor kreśli obraz rzeki pędzącej wśród skał, pieniącej fale swym rwącym nurtem:

Sarca erat Alpinos inter clarissimus amnes,

Qui montana ruens inter fragmenta sonanti

Gurgite praecipiti spumans delabitur unda.

Hic dum forte Arci per vallem et pinguia culta

Mitior allapsu leni rigat arva suasque

Attenuans vires per prata virentia fundit,

Tectus harundinea madidum caput extulit umbra

Gurgite de medio, circumspectansque subinde

Hinc atque hinc laevae deflexit lumina ripae.

20-28 (Bembo 2005: 126).

Mimo, że Katullus kreśli obraz morski, a Bembo rzeczny, to w opisach obu poetów powtarzają się niektóre słowa $\mathrm{z}$ tego samego pola semantycznego, charakterystyczne dla wodnej scenerii, takie jak na przykład gurges, spuma, czy unda. Podobny jest również motyw wyłaniających się z wody postaci. U Katullusa są to twarze zdziwionych nereid, u Bemba natomiast wilgotna głowa Sarki.

Stworzona przez obu poetów wodna sceneria staje się jednocześnie miejscem, w którym bohaterowie zakochują się w nimfach wodnych, z tą jednak różnicą, że wybranką Peleusa jest nereida, a Gardę uznać można za najadę. Doszukać się można pewnego podobieństwa w przedstawieniu momentu, gdy Peleus ujrzał Tetydę,

aequoreae monstrum Nereides admirantes.

illa, atque alia, viderunt luce marinas

mortales oculis nudato corpore Nymphas

nutricum tenus exstantes e gurgite cano.

tum Thetidis Peleus incensus fertur amore,

tum Thetis humanos non despexit hymenaeos,

15-20 (Katullus 2013: 392). 
a Sarca Gardę.

Atque hic umbrosam prope morum visa fluentes

Pectere nympha comas ad solem, quas modo fontis

Egelidi intingens secreta laverat unda.

$[\ldots]$

Zona sinum gremio disterminat; at vaga lax

Vestis turgidulum pectus cohibebat amictu,

Pectus, quod geminis tunc primum exstare papillis

Coeperat et plenos ostendere virginis annos.

[...]

Huius ut ad roseos defixit lumina vultus,

Protinus caeruleas per venas concipit ignem

Sarca. Non assuetos meminit iam volvere cursus;

29-31; 40-43; 52-54 (Bembo 2005: 126, 128, 130).

Bembo spory fragment opisu czeszącej włosy Gardy poświęca na zobrazowanie jej piersi, widocznych pod luźno opadającą suknią ${ }^{3}$. Również nereidy, którymi zachwyca się Peleus, są nagie, jednak poeta, w przeciwieństwie do Bemba, nie skupia się na szczegółach anatomicznych ich biustu.

To, co łączy dwie sceny, to nie tylko umiejscowienie ich w wodnej scenerii, ale również szybkość, z jaką bohaterowie zakochują się w pięknych nimfach. W obu przypadkach jest to miłość od pierwszego wejrzenia, uczucie nagłe, gwałtowne i palące jak ogień. Mimo, że opisy Katullusa i Bemba różnią się od siebie na poziomie językowym (język rzymskiego poety jest prosty i zwięzły, podczas gdy autor Sarki tworzy ciekawą metaforę krwi płonącej w błękitnych żyłach bohatera), to jednak odnajdujemy w nich podobny obraz. Przedstawiają oni miłość jak ogień. Co prawda Katullus wzmiankuje tylko krótko o chwili, w której oczy żeglarzy ujrzały nagie ciała nereid, autor Sarki natomiast tworzy rozbudowany, poetycki opis czeszącej włosy nimfy, jej garderoby i odsłoniętych piersi oraz obrazuje moment, w którym rzeczne bóstwo zapłonęło do niej pożądaniem. Tym, co różni początkową fazę relacji miłosnej Peleusa i Tetydy od tego, co zachodzi między bohaterami Bemba, jest wzajemność, którą odnajdujemy w Carmen 64, a której brak w epitalamium renesansowego poety. Katullus pisze, że Thetidis Peleus incensus fertur amore, tum Thetis humanos non despexit hymenaeos, Bembo natomiast obrazuje przerażenie, jakie wywołuje u nimfy zakochane bóstwo oraz opisuje zuchwałość śledzącego Gardę Sarki, gotowego posiąść ją siłą (96-103). Takie skontrastowanie postaci zawstydzonej, czy wręcz przestraszonej panny młodej ze śmiałym panem młodym wyraźnie ukazuje, że małżeństwo często wiązało się z przemocą ze strony mężczyzny i lękiem ze strony dziewczyny (Klęczar 2013: 116). Motyw ten wykorzystywany był w starożytnych epitalamiach - znajdujemy go chociażby w Carmen 61 Katullusa.

${ }^{3}$ W pisanym w volgare dialogu Bemba Gli Asolani (II 22) zawarty jest obszerny opis widocznych pod ubraniem kobiecych piersi wzorowany na przedstawieniu ciał nagich nimf $\mathrm{z}$ dydaktyczno-moralizatorskiego utworu Boccaccia Commedia delle ninfe fiorentine znanego również pod tytułem Ameto. 
Fakt, że Sarca wzorowana jest na Pieśni 64 nie oznacza wcale, że Katullus jest jedynym autorem, do którego nawiązuje Bembo. Przeciwnie, w tekście odnajdujemy wiele innych reminiscencji literatury antycznej. Renesansowy poeta chętnie wykorzystuje motywy występujące między innymi u Owidiusza czy Wergiliusza. Po poetyckim zobrazowaniu intensywnego uczucia, które trawiło Sarkę jak ogien, następuje opis ucieczki nimfy zawstydzonej miłosnym wyznaniem, aż w końcu dochodzi do spotkania zakochanego bóstwa z ojcem Gardy, który godzi się na małżeństwo córki. Bardzo podobną historię znamy z Metamorfoz Owidiusza (cf. Korenjak 2012: 530). Bez wątpienia autor Sarki świadomie nawiązuje do opowiadania o Dafne i Apollonie. Świadczyć o tym może kilka analogicznych motywów, występujących w obu tekstach. Jednym z nich jest zachowanie Sarki i Apollona wobec ściganych nimf. Obydwaj bohaterowie podkreślają, że ich ukochane nie wiedzą, kim oni są i nie są świadome, przed kim uciekają. Zarówno Apollon, jak i Sarka podczas pościgu próbują przekonać do siebie swoje wybranki, wymieniając swoje rozliczne atuty. Zwracają uwagę przede wszystkim na swoje pochodzenie oraz na władzę, którą sprawują nad ludźmi i przyrodą. Gotowi są powiedzieć bardzo dużo na swój temat, ale zdaje się, że osiągają efekt przeciwny do pożądanego i ich mowa sprawia, iż zarówno Garda, jak i Dafne uciekają przerażone i zawstydzone.

cui placeas, inquire tamen; non incola montis, non ego sum pastor, non hic armenta gregesque horridus observo. nescis, temeraria, nescis, quem fugias, ideoque fugis. mihi Delphica tellus et Claros et Tenedos Patareaque regia servit; Iuppiter est genitor. per me, quod eritque fuitque estque, patet; [...]

Plura locuturum timido Peneia cursu fugit cumque ipso verba inperfecta reliquit, tum quoque visa decens;

I 512-517; 525-527 (Ovidius ed. Anderson 1977: 17-18).

Ne tamen ipsa erres de nobis nescia: Non te Nunc aliquo credas ima de plebe rogari.

Ille ego sum aereis qui nascor in Alpibus, in quem Innumeri exonerant nivium sua pondera montes; Qui convulsa trahens non uno ex vertice saxa Vorticibus vallem rapidis hans Sarca pererro. Omnia cum libuit sterno sata, votaque spemque Agricolarum eludo; at cum tibet ${ }^{4}$, arva remisso Flumine perlustro, et florentia rura peragro, Humorem glebis tacitum atque alimenta ministrans, Ut poma evincant ramos atque horrea messes, Efficio; sic finitimis dominamur in agris.

Dicere plura parabat, at illa ruborem decentes Interfusa genas, veluti perfuderit ostro Siquis ebur, roseis vel candida lilia sertis, Effugit et medio haerentem sermone reliquit.

77-93 (Bembo 2005: 130-132).

\footnotetext{
${ }^{4}$ Poprawniejsze wydaje się słowo libet. Taka forma występuje we włoskim wydaniu (Pighi 1977: 14).
} 
Bembo, podobnie jak Owidiusz, opisując gonitwę bogów za nimfami, chętnie używa porównań zaczerpniętych ze świata zwierząt. Rzymski poeta do swojego poematu wprowadza pary zwierząt - drapieżnika i ofiarę. W tekście odnajdujemy wilka i jagnię, łanię i lwa, orła i gołębie oraz charta i zająca. Renesansowy autor nie stosuje enumeracji obecnej w Metamorfozach i porównując uciekającą Gardę i goniącego ją Sarkę używa znacznie mniejszej ilości przykładów (jeleń oraz jastrząb i gołąb).

sic agna lupum, sic cerva leonem, sic aquilam penna fugiunt trepidante columbae,

$[\ldots]$

ut canis in vacuo leporem cum Gallicus arvo vidit, et hic praedam pedibus petit, ille salutem

I 505-506; 533-534 (Ovidius ed. Anderson 1977: 17-18).

[...] illa ut propius cognovit amantem

Adventare, fugit trepidanti exterrita cursu,

Non secus ac pavitans urgente indagine cervus.

Acrius ille instat, veluti cum lapsus ab alto

Accipeter penna sequitur stridente columbam;

102-106 (Bembo 2005: 132).

Tożsama jest również reakcja uciekających, które nie mając już siły dalej biec, ratunku szukają u ojca. Warto zwrócić uwagę, że zarówno Garda, jak i Dafne są córkami bogów rzek.

viribus absumptis expalluit illa citaeque victa labore fugae spectans Peneidas undas "fer, pater," inquit "opem! si flumina numen habetis,

I 543-545 (Ovidius ed. Anderson 1977: 17-18).

Tandem ubi visa fugae minui sepes, quippe labantes

Deficiunt vires et utroque in poplite nervi,

Auxilium acclamans patrias deflectit ad undas.

$[\ldots]$

Continuo exclamans: "Pater, o pater", inquit,

"Affer opem natae, tua si tibi pignora curae,

Si de me generum, si legitimos hymenaeos,

Si gremio tenuisse unquam de coniuge natos

Sperasti nostro, non de raptore, nepotes!"

109-111; 115-119 (Bembo 2005: 132, 134).

W kolejnych wersach Bembo zamieszcza epickie przedstawienie podwodnej siedziby Sarki (177-182) podobnej w swym przepychu do błyszczącego złotem i skrzącego się srebrem pałacu Peleusa (43-46). W jednej z wielu komnat groty rzecznego bóstwa, na nóżkach z kości słoniowej wznosi się imponujących rozmiarów małżeńskie łoże $\mathrm{z}$ ramą ozdobioną złotem. $\mathrm{Z}$ jednej strony pokryte jest purpurową narzutą, z drugiej zaś wielobarwnymi wełnianymi kobiercami. Co prawda opis łoża Sarki różni się nieco od słynnego przedstawienia tkaniny 
ukazującej historię Tezeusza i Ariadny, jednak sama idea umieszczenia w tekście ekfrazy małżeńskiego posłania niewątpliwie zaczerpnięta została z Pieśni 64. Warto zauważyć, że Katullus, opisując narzutę przygotowaną dla Tetydy, tworzy rozbudowany epyllion, podczas gdy w Sarce wyodrębnić można trzy krótsze opisy. Pierwszy z nich (197-215) dotyczy rzeźbionej w złocie i kości słoniowej ramy łoża, przedstawiającej Wenus na muszli otoczoną przez nereidy i putta, mogącą skojarzyć się ze słynnym obrazem Botticellego lub z Galatea pędzla Rafaela ${ }^{5}$. Drugą ekfrazę (216-219) stanowi opis purpurowej narzuty, ozdobionej złotym ostem najeżonym kolcami oraz innymi ornamentami roślinnymi. Ostatnia natomiast (220-233) prezentuje wielobarwne wełniane kobierce utkane przez zręczne nimfy, przedstawiające satyrów, stado jeleni, zające o długich uszach oraz zwinne sarny. Zarówno Katullus, jak i Bembo, kreśląc obraz małżeńskiego posłania, sięgają do tematów mitologicznych, $\mathrm{z}$ tą jednak różnicą, że ten pierwszy uwage czytelnika kieruje na emocje i uczucia związane z tragiczną historią Ariadny, renesansowy poeta natomiast skupia się raczej na jak najdokładniejszym przedstawieniu samych obrazów, nie opisując żadnej konkretnej historii. Innym podobieństwem łączącym posłania Peleusa i Sarki jest materiał, z którego zostały one wykonane. W obydwu tekstach łoża wyrzeźbione są z kości słoniowej, narzuty natomiast wykonano z purpury. Purpurę w epoce antycznej uważano za najcenniejszą barwę. W starożytnym Rzymie zarezerwowana była ona tylko dla najwyższych urzędników państwowych (Gage 2008: 25). W starożytnej Grecji natomiast stosowano ją między innymi jako kolor uświęcający śluby (Gage 2008: 26), co tłumaczy wybór tej właśnie barwy na posłania dla bohaterów dwóch epitalamiów. Warto wspomnieć, że purpura nie była jedynie określeniem koloru, ale odnosiła się również do samej tkaniny (Gage 2008: 80), co znajduje zastosowanie zarówno w katullusowej pieśni, jak i w poemacie Bemba. Mimo znaczących różnic między antycznymi a renesansowymi terminami dotyczącymi barw (Gage 2008: 120), zastosowanie purpury w Sarce pełni tą są funkcję, co w Pieśni 64.

Centralnym punktem renesansowego poematu jest przepowiednia wieszczki Manto, będącej jednym z gości na uczcie weselnej. Po obrzędzie deductio tebańska prorokini udaje się wraz z parą młodą do komnaty małżeńskiej, aby w obecności Hymena, Junony i innych pomniejszych bóstw, obecnych podczas nocy poślubnej, zdradzić nowożeńcom decreta deorum. Manto wyjawia, że ze zjednoczenia wód obu rzek, Sarki i Benakusa, powstanie wielkie jezioro, które rozleje się po całej dolinie. Jego panią będzie nimfa Garda. Okoliczni mieszkańcy wznosić będą wspaniałe miasta na brzegach wód jej królestwa, a śmiali żeglarze będą pruć jej fale. Tam też królowa jeziora wyda na świat rzekę Mincio, która nie mogąc pozostać w granicach matczynego królestwa, z całą swą siłą odziedziczoną

${ }^{5}$ Na podobieństwo opisu do obrazu Botticellego Narodziny Wenus zwraca uwagę G.B. Pighi (1977: 69), natomiast o jego analogii z freskiem Rafaela Galatea z Villa Farnesina w Rzymie wzmiankuje M.P. Chatfield (2005: 265). 
po ojcu przełamie zapory i rozleje się w głąb italskich ziem. Mincio założy słynne miasto, które otoczy stawami pełnymi ryb. Mowa oczywiście o Mantui okrążonej od północnego wschodu i zachodu czterema jeziorami.

Warto zastanowić się, dlaczego to właśnie Manto, a nie na przykład Parki, tak jak ma to miejsce w Katullusowej Pieśni 64, przepowiada przyszłe losy potomstwa pary młodej. Z całą pewnością wybór autora Sarki nie był przypadkowy. Oparł się on na tradycji mitologicznej łączącej tebańską wieszczkę z okolicą Jeziora Garda oraz z powstaniem Mantui. Poeta wskazuje na miejsce zamieszkania Manto, pisząc, że zjawiła się ona na ślubie Sarki, aby podzielić się radosną przepowiednią z nowymi sąsiadami. W Boskiej Komedii (Piekło 20, 55-92) czytamy o Manto, która ,uciekłszy z Teb po śmierci swego ojca, aby wymknąć się spod tyranii Kreonta, zatrzymała się w miejscu, gdzie później miała wyrosnąć Mantua" (Kuciak 2006: 168). Przy okazji opisywania początków miasta narodzin Wergiliusza Dante kreśli również malowniczy obraz okolicy Jeziora Garda oraz lewego dopływu Padu.

Według Wergiliusza (Aeneis X 198-200) natomiast założycielem jego ojczystego miasta był Oknus, czy też Auknus, syn boga rzeki Tybru i Manto, niekiedy identyfikowany też z Bianorem (Grimal 1997: 54). Na tej wersji mitu częściowo opiera się autor Sarki. Można jednak zauważyć pewną niekonsekwencję, bowiem wprowadzając do poematu postać prorokini, poeta przedstawia ją jako matkę tego, który założył miasto ukochane przez Muzy i nadał mu jej imię (324-327). W dalszej części utworu natomiast to już Mincio, nie Oknus, jest założycielem Mantui (467-470).

Warto wspomnieć o Boccacciu, który w dziele $O$ stynnych kobietach podaje mit o początkach Mantui, będący połączeniem wersji Dantego i Wergiliusza (De muleribus claris XXX). Po wojnie tebańskiej Manto miała dotrzeć do Italii, gdzie ze związku z Tyberinusem urodziła syna Cithconusa ${ }^{6}$, z którym udała się w bagniste okolice Jeziora Garda. Tam też spędziła resztę życia. Po śmierci Manto Cithconus założył miasto $\mathrm{w}$ miejscu, gdzie została ona pochowana i nazwał je Mantua od imienia matki.

Pomijając położenie geograficzne, które w naturalny sposób łączy Mincio z Jeziorem Garda i Mantuą, warto odnieść się do śladów tych związków w mitologii. Autor Sarki w swoim poemacie czyni z Gardy matkę rzeki Mincio. Nawiązuje on więc do Wergiliusza, który pisał o Mincjuszu, będącym synem Benaka (Aeneis X 205-206). Również u Dantego czytamy o rzece, której woda nie mieści się w jeziornym łonie i ,już nie Benako, a Mencio się nazywa" (Alighieri 2006: 168).

Dalsza część przepowiedni Manto dotyczy potomka Mincio, a więc wnuka pary młodej. Jest to historia, która nie występuje w klasycznej mitologii grecko-rzymskiej. Autor tworzy nowy mit, wykorzystując jednak stare motywy. Według prorokini po dopłynięciu do Mantui Mincio połączy się z piękną nimfą Maią

${ }^{6}$ „Boccaccio dysponował rękopisem Eneidy zawierającym błędną lekcję wersu: Ille etiam patriis agmen ciet Ocnus ab oris. Zamiast ciet Ocnus był tam Cithconus. Tak więc syn Manto miał na imię Oknus" (Olszaniec, Rzepkowski 2013: 184). 
- córką Atlasa i matką Hermesa, która wkrótce wyda na świat niezwykłego potomka, wielkiego poetę - Wergiliusza. Do nowo narodzonego dziecka przybędą Muzy i Gracje, aby na polecenie Wenus piersi Mai zamiast mlekiem napełnić ambrozją (484-487, 490-492). To właśnie Wenus, pragnąc, by pisarze rozsławili Eneasza na równi z Achillesem, uczyni Wergiliusza największym wieszczem wśród wszystkich poetów rzymskich i greckich.

Calliope, atque aliis curam partita Camoenis. Hae primum ex ipsa cui innixa puerpera lauro Infantem ediderat, decerptis frondibus illum Involvunt; [...] Mox ubi ${ }^{7}$ ambrosium infundunt pro lacte liquorem Certatim Charites, Veneris quod munus ab alto Demissum attulerant haec ipsa ad munia caelo". 484-487; 490-492 (Bembo 2005: 162).

Drzewo, przy którym puerpera infantem ediderat i z którego Muzy zerwały listki laurowe, aby owinąć nimi nowo narodzonego Wergiliusza, jest oczywistym nawiązaniem do znanej z Hymnów homeryckich palmy, przy której urodził się Apollo. Natomiast Muzy, karmiące ambrozją dopiero co wydanego na świat poetę, skojarzyć się mogą z Temidą, podającą nektar nowo narodzonemu Apollonowi.

Zaraz Latonę bóle chwyciły i rodzić poczęła.

W krąg ramionami palmę objęła, kolana oparła

Na delikatnej murawie - radośnie zaśmiała się ziemia.

Dziecię na świat wyjrzało, boginie zaś wzniosły okrzyki.

Wówczas cię, Febie donośnie krzyczący, boginie obmyły

Wodą piękną, świętą i czystą, okryły pieluszką

Nową, białą i miękką, przepaską ją złotą związawszy.

Nie ssał piersi matczynej Apollon, co złoty miecz nosi,

Lecz mu Temida nektaru, a także rozkosznej ambrozji

Swymi boskimi rękami podała;

III 116-125 (Appel 2001: 87).

W ostatniej części przepowiedni Manto następuje charakterystyka twórczości Wergiliusza oraz podkreślona zostaje nieśmiertelność jego geniuszu, który przejawiać się będzie w osobach późniejszych naśladowców poety, za przykład których Bembo podaje Stacjusza, Pontana i Sannazara, pokrótce przedstawiając ich twórczość. Przepowiednia kończy się hymnem skierowanym do „rodzica wszystkich wieszczy" oraz życzeniami dla nowożeńców.

Trudno nie zauważyć analogii występującej między przepowiednią Manto a pieśnią Parek z Carmen 64. Zarówno tebańska wieszczka, jak i boginie życia i śmierci zapowiadają wielkość i sławę potomstwa pary młodej:

nascetur vobis expers terroris Achilles, hostibus haud tergo, sed forti pectore notus, qui persaepe vago victor certamine cursus flammea praevertet celeris vestigia cervae.

338-341 (Katullus 2013: 416).

\footnotetext{
${ }^{7}$ Powinno być ori. Taka forma występuje we włoskim wydaniu (Pighi 1977: 38).
} 


\section{Dii magni, qualem nobic quantumque nepotem \\ Nostra haec Maia dabit! Felicior altera prole \\ Non erit in terris nec toto clarior orbe. \\ 478-480 (Bembo 2005: 160, 162).}

Przyszłą potęgę Achillesa porównać można z talentem Wergiliusza i jego późniejszych naśladowców. W ten sposób moc poezji stawiana jest na równi z wielkością herosa. Można by rzec, że Wergiliusz w Sarce staje się Achillesem poezji.

Ani Sarca, ani Pieśń 64 nie są związane z żadną historyczną uroczystością ślubną i nie mają charakteru obrzędowego. Ich głównym tematem są mitologiczne zaślubiny - w przypadku Katullusa bohaterami są znane postaci mitologiczne, autor Sarki natomiast tworzy zupełnie nowy mit, co stanowiło popularną strategię literacką w epoce renesansu. U Jacoba Burckhardta czytamy: ,[...] godne uwagi są nowo powstałe legendy, zaludniające najpiękniejsze okolice Włoch bogami, nimfami, duchami opiekuńczymi [...]. Za arcydzieło tego rodzaju należy uważać Sarkę Pietra Bembo” (1991: 162). Burckhardt pisze też o „,...] podwójnym znaczeniu, jakie starym bogom nadawano w epoce Odrodzenia; z jednej strony, zastępują oni pojęcia ogólne, usuwając postacie alegoryczne, z drugiej wszelako tworzą wolny, samoistny element poezji, uzmysławiając piękno niezależne, mogące w coraz to innej formie stanowić składnik wszelkiej twórczości poetyckiej." (1991: 162). Sarkę można uznać za doskonały przykład nowego mitu opartego na starożytnych fundamentach. Autor poematu w umiejętny sposób łączy to, co klasyczne, z tym, co mu współczesne. Tworzy mozaikę motywów antycznych i mitologicznych zaczerpniętych z literatury greckiej i rzymskiej, uzupełnioną jednak nawiązaniami renesansowymi. Wplata do swojej opowieści, wyjaśniającej powstanie Jeziora Garda i rzeki Mincio, hołd złożony Wergiliuszowi, związany $\mathrm{z}$ kwitnącym w renesansie kultem poety.

Ponadto Sarka jest epyllionem o charakterze ajtiologicznym. Funkcja ajtiologiczna stanowiła ważny aspekt $\mathrm{w}$ twórczości poetyckiej epoki odrodzenia. Jednym z renesansowych poetów, który chętnie wyjaśniał powstanie gwiazdozbiorów, gatunków roślin, czy rzek był Giovanni Pontano ${ }^{8}$. W swojej pierwszej eklodze (Lepidina) o tematyce bardzo zbliżonej do Sarki, opowiada o zaślubinach syreny Partenope, będącej personifikacją Neapolu, z wyschniętą już dziś rzeką Sebeto.

Związki międzytekstowe w okresie renesansu miały najczęściej charakter alegacyjny (Fulińska 1997: 5), czyli polegający na potwierdzeniu uczestnictwa autora w wielkiej tradycji (Głowiński 1984: 90). Alegacyjność Sarki zawiera się w przywołaniu przez Bemba słów poetów antycznych w celu nadania autorytetu własnym. Jednak, jak zauważa Agnieszka Fulińska, intertekstualność postrzegana

${ }^{8}$ W poemacie dydaktycznym Urania Pontano opłakuje śmierć swojej córki Lucii, która została zamieniona w gwiazdę. W eklodze Coryle poeta opisuje przemianę tytułowej nimfy w drzewo leszczyny. 
była „nie tylko przez pryzmat autorytetu, ale także faktycznych strukturalnych i semantycznych relacji pomiędzy utworem naśladowanym i naśladującym" (Fulińska 1997: 14). Powyższa analiza ukazuje, że zależności intertekstualne łączą Sarkę z hipotekstami na różnych płaszczyznach. Największe podobieństwo utworu Bemba do tekstów pierwotnych widoczne jest na poziomie elementów świata przedstawionego. W renesansowym poemacie obecnych jest wiele motywów tożsamych z utworami, na których wzorował się Bembo. Analogie stylistyczne i językowe są nieznaczne i ograniczają się raczej do wykorzystania słów z podobnego pola semantycznego w niektórych fragmentach, czy też zastosowania podobnej figury retorycznej (ekfraza), niż językowego współzawodniczenia. $\mathrm{Z}$ analizy wynika zatem, że emulacja Bemba $\mathrm{z}$ autorami antycznymi dotyczy głównie przetwarzania i adaptowania treści.

Chociaż Sarca wzorowana jest głównie na Carmen 64 Katullusa (mimo że w dwóch utworach uwypuklone zostały nieco odmienne aspekty), to poprzez misternie splecioną sieć intertekstualnych powiązań, Bembo nawiązuje również do innych autorów, głównie do Owidiusza i Wergiliusza. Sarca jest zatem wyrazem poli, nie monoimitacji, której zwolennikiem był Bembo 9 . Mimo to, w końcowej części swojego poematu renesansowy poeta przywołuje miasto Sirmione, wysyłające na ucztę weselną Gardy i Sarki dziewczęta śpiewające Katullusowe wersy. Ten zabieg uznać można za ukłon w stronę poety, z którym decyduje się współzawodniczyć Bembo:

Aemula quis totidem mittebat clara puellas

Sirmio, quae docti numeros cantare Catulli

Assuetae, Aeoliis poterant contendere plectris.

257-259 (Bembo 2005: 144).

To właśnie głównie z tym rzymskim autorem, najbardziej chyba związanym z okolicą Jeziora Garda z powodu swojej pieśni o Sirmio ${ }^{10}$ (Carmen 31), rywalizuje Bembo.

\section{Bibliografia}

Bembo, P. (2005). Lyric Poetry. Etna. Trans. M.P. Chatfield. Cambridge-Massechusetts-London: Harvard University Press.

Burckhardt, J. (1991). Kultura Odrodzenia we Wtoszech. Próba ujęcia. Przeł. M. Kreczkowska. Warszawa: Czytelnik.

Chatfield, M.P. (2005). Introduction. W: Bembo P., Lyric Poetry. Etna (s. VII-XX). CambridgeMassechusetts-London: Harvard University Press.

9 Swoje stanowisko odnośnie imitacji i emulacji Bembo wyraził w korespondencji z Gianfrancesckiem Pico della Mirandola. (cf. Fulińska 2000).

${ }^{10}$ Katullus miał willę w Sirmione. Jej pozostałości znane jako Groty Katullusa są wciąż dostępne dla turystów. Bembo zapewne znał to miejsce. 
Elwert, W.T. (1969). „Il Lago di Garda nella poesia italiana del Cinquecento”. Il Lago di Garda, Atti del Congresso internazionale promosso dall'Ateneo di Salò II. 203-245. Salò: Atteneo di Salò.

Fulińska, A. (1997). „Renesansowa aemulatio: alegacja czy intertekstualność?”. Teksty Drugie 4. $5-15$.

Fulińska, A. (2000). Naśladowanie i twórczość: renesansowe teorie imitacji, emulacji i przekładu. Wrocław: FNP.

Gage, J. (2008). Kolor i kultura. Teoria i znaczenie koloru od antyku do abstrakcji. Przeł. J. Holzman. Kraków: Universitas.

Głowiński, M. (1986). „O intertekstualności”. Pamiętnik Literacki 4. 90-91.

Grimal, P. (1997). Stownik mitologii greckiej i rzymskiej. Wrocław: Ossolineum.

Hymny homeryckie. (2001). Przeł. W. Appel. Toruń: Algo.

Katullus. (2005). Poezje. Przeł. A. Świderkówna. Wrocław: Ossolineum deAgostini.

Katullus. (2013). Poezje wszystkie. Przeł. G. Franczak, A. Klęczar, Kraków: Homini.

Klęczar, A. (2013). Wstęp. W: Katullus, Poezje wszystkie. Przeł. G. Franczak, A. Klęczar. Kraków: Homini. 7-118.

Korenjak, M. (2012). Short Mythological Epic in Neo-Latin Literature. W: Baumbach, M., Bär, S. (red.), Brill's Companion to Greek and Latin Epyllion and its reception. Leiden-Boston: Brill.

Kuciak, A. (2006). Przypisy. W: Alighieri, D. Boska komedia. Przeł. A. Kuciak. Poznań: Wydawnictwo AA.

Mai, A. (1942). Spicilegium Romanum (vol. VIII). Roma: Typis Collegii Urbani.

Morsolin, B. (1886-1887). „Il Sarca, poemetto latino di Pietro Bembo”. Atti del Reale Istituto Veneto di scienze lettere ed arti, dal novembre 1886 all'ottobre 1887 (vol. V, serie VI). Venezia: Tipografia G. Antonelli. 229-265.

Olszaniec, W., Rzepkowski, K. (2013). Przypisy. W: Boccaccio, G., O stynnych kobietach. Przeł. P. Bańkowski. Warszawa: Wydawnictwo Uniwersytetu Warszawskiego.

Ovidius. (1977). Metamorphoses. W.S. Anderson (ed.), Leipsig: B. G. Teubner.

Pecoraro, M. (1959). Per la storia dei carmina del Bembo. Una redazione non vulgata. Roma: Istituto per la collaborazione culturale.

Pighi, G.B. (1974). Sarca. Poema del XVI secolo. Testo latino e traduzione italiana con un saggio critico. Arco: Cartiera di Arco-Stamperia Valdonega.

Piovesan, E. (1974). "L'autore del poemetto Sarca". Atti e memorie della Accademia di Agricoltura, Scienze e Lettere di Verona, anno accademico 1973-1974 (vol. XXV, serie 6). 203-245.

Schönberger, O. (1994). Sarca: Petrus Bembus: Einleitung, völlständiger Text, erste Übersetzung und Anmerkungen. Würzburg: Königshausen \& Neumann.

Zeno, A. (1782). Lettere (vol. III). Venezia: Apresso Francesco Sansoni.

Mgr Daria Kowalczyk-Cantoro - graduate of Classical Philology and Mediterranean Culture at the University of Wrocław. Since 2014 she has been associated with the Department of Italian Studies at the Institute of Romance Philology at the University of Wrocław, where she currently works as a lecturer. She is in the process of writing her $\mathrm{PhD}$ thesis entitled "Pietro Bembo. At the junction of literary traditions".

e-mail: daria.kowalczyk@uwr.edu.pl 